\title{
IMMUNO-ELECTROPHORETIC ANALYSIS OF PROTEINS IN SERUM AND SYNOVIAL FLUID IN RHEUMATOID ARTHRITIS AND ANKYLOSING SPONDYLITIS
}

\author{
BY \\ STEFAN MACKIEWICZ* AND WLADYSLAW FENRYCH \\ From the Third Medical Clinic, Academy of Medicine, Posnan, Poland
}

\begin{abstract}
Among the systemic manifestations of rheumatic disease it is customary to include a number of quantitative changes in the constituents of plasma, together with abnormalities in immunological and other properties of serum. Although most of these changes are neither uniquely nor constantly demonstrable in this group of diseases or in any member of the group, it is likely that information on the true nature of the underlying changes in plasma constituents will contribute to an understanding of the fundamental significance of these phenomena.

A complete list of all the changes so far recorded is not relevant to this report, but among those more frequently demonstrable may be included an increase in the total gamma globulin, and in alpha-1 and alpha-2 glycoproteins as shown by paper electrophoresis, elevation of the erythrocyte sedimentation rate, and the presence of demonstrable amounts of one or more "rheumatoid factors", having in common the property of reacting with denatured gamma globulin.
\end{abstract}

One or more fractions reacting in vitro with nuclear material are demonstrable in sera from a minority of patients with rheumatoid arthritis, and also from the majority of patients with systemic lupus erythematosus, in whom a number of other serum factors have been described which react in vitro with more or less denatured constituents of cells or organs.

The immuno-electrophoretic technique of Grabar and Williams (1953) provides an approach to the problem of exploring the nature of abnormally reactive components in serum and other body fluids, in that it permits the identification and separation of a far larger number of distinct protein fractions than is possible by any other method used alone. The nature of the physiological properties

- Present address: Rheumatic Diseases Unit, Northern General Hospital, Edinburgh. of many of these fractions remains unknown, and indeed it would be unreasonable to conclude at present that fractions identified from their associated electrophoretic and antigenic properties are necessarily also functional entities. Nevertheless, it is likely that immuno-electrophoretic techniques can now provide qualitative and semi-quantitative data on the constituents of serum in health and disease which may ultimately be integrated with the results obtained by exploration of the functional characteristics of whole serum and its constituent proteins.

Schmid and MacNair (1956) were the first to use immuno-electrophoretic techniques to study the proteins of serum and synovial fluid from patients with rheumatic diseases; they confirmed that the individual proteins from these two sources had similar electrophoretic and antigenic properties.

Increased amounts of alpha-1 and alpha-2 glycoproteins and beta-2 macroglobulin were found in sera from patients with rheumatoid arthritis or rheumatic fever by Cleve and Hartmann (1957) and by Cleve (1958). No correlation was apparent between the increase in beta- 2 macroglobulin and the Rose-Waaler haemagglutination titre in the sera from patients with rheumatoid arthritis, and the protein changes in this disease and in rheumatic fever were interpreted as a manifestation of active inflammation. The authors also investigated the proteins in synovial fluid where the concentration of fractions of high molecular weight was lower than in serum.

Increased amounts of alpha-2 glycoproteins (i.e. haptoglobin and alpha-2 macroglobulin) in the serum of patients with rheumatoid arthritis were also reported by Fenrych, Jazienicki, Mackiewicz, Mackiewicz, and Twardowski (1959). Moreover, the latter component was increased in twenty of the 42 sera from patients with various forms of chronic 
arthritis examined by Francq, Eyquem, Podliachouk, and Jacqueline (1959). By specially prepared antisera, the authors demonstrated a correlation between the increase in beta- 2 macroglobulin and gamma globulin, and the titre for agglutination of sensitized sheep erythrocytes.

From the foregoing it is evident that increased amounts of certain fractions of the alpha and beta globulins and of gamma globulins are frequently demonstrable in sera from patients with rheumatoid arthritis, although the relationship between these changes and other manifestations of the disease remains uncertain.

The present report is concerned with further attempts to characterize changes in protein fractions in serum and synovial fluid associated with rheumatoid arthritis.

\section{Material and Methods}

The sera investigated were obtained from 43 patients with rheumatoid arthritis and 22 with ankylosing spondylitis and from twenty healthy individuals (with a normal paper electrophoresis pattern). The patients with rheumatoid arthritis included eighteen men and 25 women between the ages of 22 and 65 years, the duration of disease being between 1 and 15 years. The diagnosis was based upon typical clinical findings and confirmed by radiography of the joints. Two patients in this group also had chronic renal functional impairment with oedema and proteinuria, and in one of the two the presence of amyloidosis was demonstrated by a modification of the congo red test of Bennhold (Chodera and Mackiewicz, 1958), and by gum biopsy. The haemagglutination test of Rose and Heller was performed on sera from twelve of the patients with rheumatoid arthritis, and the titre was significantly raised in each of them.

The group of patients with ankylosing spondylitis included twenty men and two women between the ages of 24 and 57, the duration of disease being between 2 and 9 years. The diagnosis was made from clinical findings and radiological evidence of bilateral sacro-iliitis; in two patients there was a previous history of rheumatic fever and in one there were signs of mitral stenosis and incompetence. Sera from eight of these patients were tested by the method of Rose and Heller and in all of them the haemagglutination titre fell within the normal range.

The erythrocyte sedimentation rate (E.S.R.) was measured by the Westergren method in all patients in the rheumatoid and spondylitic groups. In eleven it exceeded $100 \mathrm{~mm} . / \mathrm{hr}$, in seventeen it was between 60 and $99 \mathrm{~mm} . / \mathrm{hr}$, and in the remaining 37 it was between 40 and $59 \mathrm{~mm}$. in the first hour. Thus all the patients showed a significant elevation, and from this and other evidence it was concluded that they all had active disease. The haemoglobin and erythrocytes were determined in the blood of these patients in an automatic apparatus. A normochromic or hypochromic anaemia was present in nine patients with rheumatoid arthritis and in six $\frac{\mathbb{2}}{3}$ with ankylosing spondylitis.

In the sera from patients and healthy subjects, totalon protein was determined by the biuret method and the major protein fractions by filter paper electrophoresis.

All immuno-electrophoretic studies on sera in theseo investigations were performed in duplicate. Synovialo fluids obtained from the knee joints of a number of the patients with rheumatoid arthritis were also subjected to immuno-electrophoresis, as were samples of urine from the two patients with renal disease. In the immuno-electrophoretic procedure the sera, synovial fluid, and urine were studied in terms of their antigenic:constituents. The antisera included polyvalent rabbit $\vec{\omega}$ antihuman serum prepared by immunizing animals witho whole human serum either pooled or from individuals, following the procedure described by Cleve and Hartmann (1957). Two rabbits were immunized with serum fromo normal subjects, two with serum from the two patients $\omega$ with renal disease, and eight with sera of a high haem- $N$ agglutination titre obtained from patients with rheumatoidor arthritis. Two of the latter eight rabbits showed signs? such as loss of weight, roughening of the fur, andultimately paralysis of the hindquarters. Histologicales examination of tissues obtained from those rabbits ato autopsy showed widespread arteritis, together with diffuse glomerulitis, the lesions being similar to those previously observed in mice and rats after the intravenous administration of soluble antigen-antibody $\vec{c}$ complexes (McCluskey, Benacerraf, Potter, and Miller,o 1960; Benacerraf, Potter, McCluskey, and Miller, 196.

The remaining ten rabbits showed no adverse effectso from immunization. After immunization the rabbits were bled from the carotid artery and the antisera obtained were tested initially by double-diffusion in agaro with whole or fractionated human serum (Ouchterlony, $\mathbb{Q}$ 1953). When used in immuno-electrophoresis the anti $-\Rightarrow$ sera produced at least fourteen and as many as nineteeno distinct precipitin lines with a variety of human sera? There was no constant difference in the number of lines produced with the antisera prepared against normap. human serum, and the number produced with the antisera against serum from patients with rheumatoide arthritis.

The known antigenic components of serum represented. by the precipitin arcs were identified by their character? istic distribution on immuno-electrophoresis, by means of specific univalent antisera to individual componentso of serum (obtained from Behring and Co. Ltd., Marburg Lahn), and by the use of differential staining techniques for lipoprotein. The following univalent antisera were used: anti-prealbumin, anti-albumin, anti-alpha-2 macro $N$ globulin, anti-alpha-2 lipoprotein, anti-beta-1 lipo= protein, and anti-gamma globulin.

Sera obtained from the rheumatic patients were compared with those from healthy subjects in terms of the number and intensity of precipitin lines apparens after electrophoresis followed by double diffusion with particular antisera. Two of the sera from healthyos individuals were chosen as standards of normality and all others were compared with these in terms of the 
presence of particular immuno-electrophoretic components and on the basis of comparative quantitation of these components. To measure the relative concentrations of a particular component in two different sera, aliquots of antiserum were absorbed with varying amounts of one serum. The absorbed aliquots were then tested in immuno-electrophoresis to determine the amount of the absorbing serum sufficient to prevent formation of a precipitin line corresponding with the component in question. Thus a relatively higher concentration of a particular antigen in one of the two sera was reflected by the relatively smaller volume of serum required to absorb the specific antibody. The procedures followed in the present studies were evolved on the basis of this principle, but were necessarily simplified in order to permit the analysis of a large number of sera. As an alternative and more satisfactory method for semiquantitative determination of the relative concentrations of components in two sera, polyvalent and univalent antisera were set up against several dilutions of both, and the dilution which prevented formation of the particular precipitate was recorded for each serum. The serum requiring more dilution for this effect was considered to have a higher concentration of the component in question.

The immuno-electrophoretic technique is a modification, introduced by Fenrych and others (1959), of the micro-method described by Scheidegger (1955). Electrophoretic separation of the sera was produced in 2 per cent. agar-gel in barbiturate buffer $\mathrm{pH} 8 \cdot 2 ; 0.1 \mathrm{M}$. on microscope slides measuring $26 \times 76 \mathrm{~mm}$. The serum was inserted in a round well $(0.9 \mathrm{~mm}$.) placed centrally. After electrophoretic separation, antisera were inserted into longitudinal troughs $(36 \times 1 \mathrm{~mm}$.) cut in the gel near one or both sides of the slide and parallel to the axis of electrophoretic migration. In this system lines of precipitate appear at the interfaces between components of serum diffusing outwards from the axis of electrophoretic migration and their specific antibodies diffusing inwards from the troughs containing antiserum. The position, shape, and density of the precipitates so formed are determined by the interaction of factors, including electrophoretic mobility of antigen, the diffusion constants of antigen and antibody, the relative concentrations of these reagents, and their optimum combining ratios. The large number of distinct precipitates formed with a complex system of antigens and antibodies depends upon the extremely low probability that two or more antigen-antibody pairs in the system will be identical in so many different respects.

\section{Results}

The characteristic immuno-electrophoretic components of human serum are shown in Fig. 1, which, for clarity, is a diagram based upon the precipitin patterns identified with this technique. In this diagram the components are named according to the terminology of Grabar (1960). The alpha-2 lipoproteins are further subdivided into "fast" and "slow" components, and "alpha-1 principale" $\left(\mathrm{S}_{20}=3.5 \mathrm{~Sv}\right.$.) is designated "main alpha-1". The precipitates so far identified are labelled, and it should be noted that the components do not form groups limited to the major bands produced by simple electrophoresis. This may result from the free radial diffusion of all components occurring in immuno-electrophoresis during the phase necessary for formation of the specific precipitates. Such diffusion complicates the interpretation of the results of immuno-electrophoresis in terms of those of simple electrophoresis, and the two methods of analysis are complementary rather than equivalent.

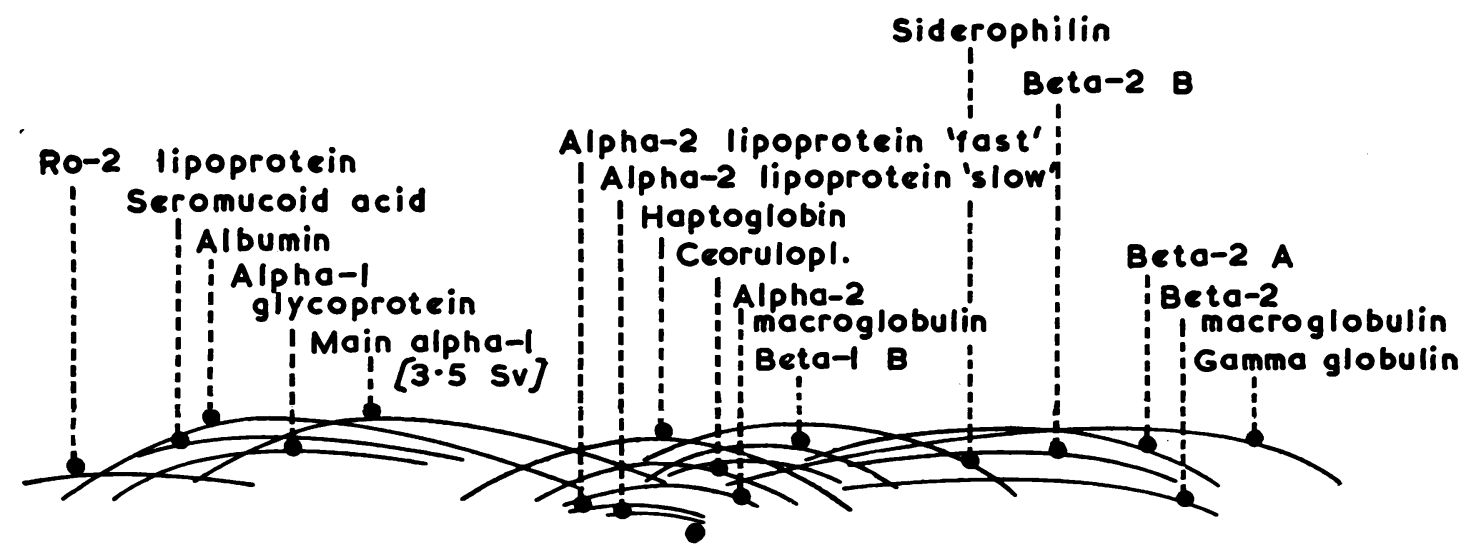

Fig. 1.-Immuno-electrophoretic components of serum.

Diagram constructed from a number of studies and including the components so far identified. 
TABLE

COMPARISON OF RESULTS OF IMMUNO-ELECTROPHORESIS WITH THOSE OF PAPER ELECTROPHORESIS

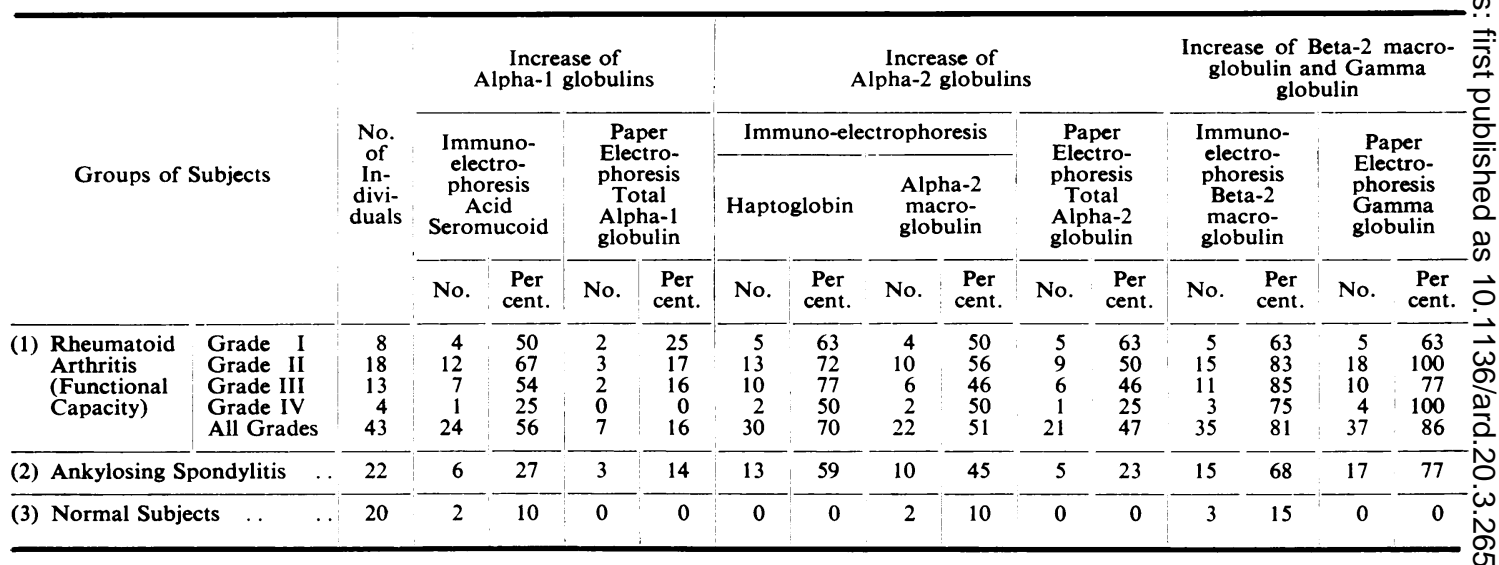

For this reason data obtained by both the methods presented in the Table are arranged to show the semiquantitation of immuno-electrophoretic components alongside quantitation of the major electrophoretic fractions likely to include part or all of these components.

Except in the case of albumin and gamma globulin, which are relatively homogenous, there was little or no quantitative correlation between the immunoelectrophoretic components and the corresponding major protein fractions, at least in terms of the observed differences between sera obtained from healthy individuals or patients, and the standard sera obtained from the other healthy individuals. Excessive amounts of individual components were observed more frequently in the sera of rheumatic patients than in those of healthy individuals, but these changes were not clearly related either to other features of rheumatoid arthritis, such as elevation of the erythrocyte sedimentation rate or severity of the disease in terms of functional impairment, or to duration of the disease. No attempt will be made to interpret the following changes observed in presently identified immuno-electrophoretic components of the major electrophoretic fractions.

Pre-albumin.-Ro-2 lipoprotein is a component of pre-albumin. The latter fraction is usually found in barely detectable quantities, if at all, in normal serum. The ro-2 lipoprotein was readily demonstrated in the sera from four patients with rheumatoid arthritis, including the two with complicating renal disease, and it was also demonstrable in the serum of one of the patients with ankylosing spondylitis. The fraction was more readily demonstrable with the antisera prepared against the serum of patients with renal disease, because of the pre- $\vec{c}$ sence of relatively greater amounts of the appropriate $\mathbb{D}$ antibody.

Albumin.-This was represented by a single precipitin line produced by all the sera tested, byt ${ }_{\vec{C}}$ the density of the precipitate varied in the proportiog to the concentration of albumin determined paper electrophoresis (Figs 2, 3, 4, opposite, a Fig. 5, overleaf).

Alpha-I Globulin.-Increased amounts of acid seromucoid were found in 24 (56 per cent.) of the $\mathbb{D}$ sera obtained from the patients with rheumatoid $\stackrel{2}{\overrightarrow{7}}$ arthritis, in six (27 per cent.) of those from the $\frac{0}{3}$ patients with ankylosing spondylitis, and in two (10 per cent.) of those from healthy individuals. Although there was much variation in the density of the precipitin lines of other components of this fraction, no consistent pattern could be discerned 0 (Fig. 2).

Alpha-2 Globulin.-All the sera from the patients with rheumatoid arthritis and sixteen ( 75 per cent.)응 of those from the patients with ankylosing spondylitis gave rise to precipitin lines of markedlyo increased density corresponding with components of alpha-2 globulin (Figs 2 and 4). On the basis of $\widetilde{N}$ the semiquantitative procedures, thirty ( 70 per cent.) $N$ of the sera from patients with rheumatoid arthritis N contained increased amounts of the haptoglobin $\omega_{-}$ component and 22 (51 per cent.) of these sera also contained increased amounts of the alpha-2 macro- $\frac{C}{0}$ globulin component (Figs 2 and 4). The sera from patients with rheumatoid arthritis containing increased amounts of alpha-2 macroglobulin included 0 


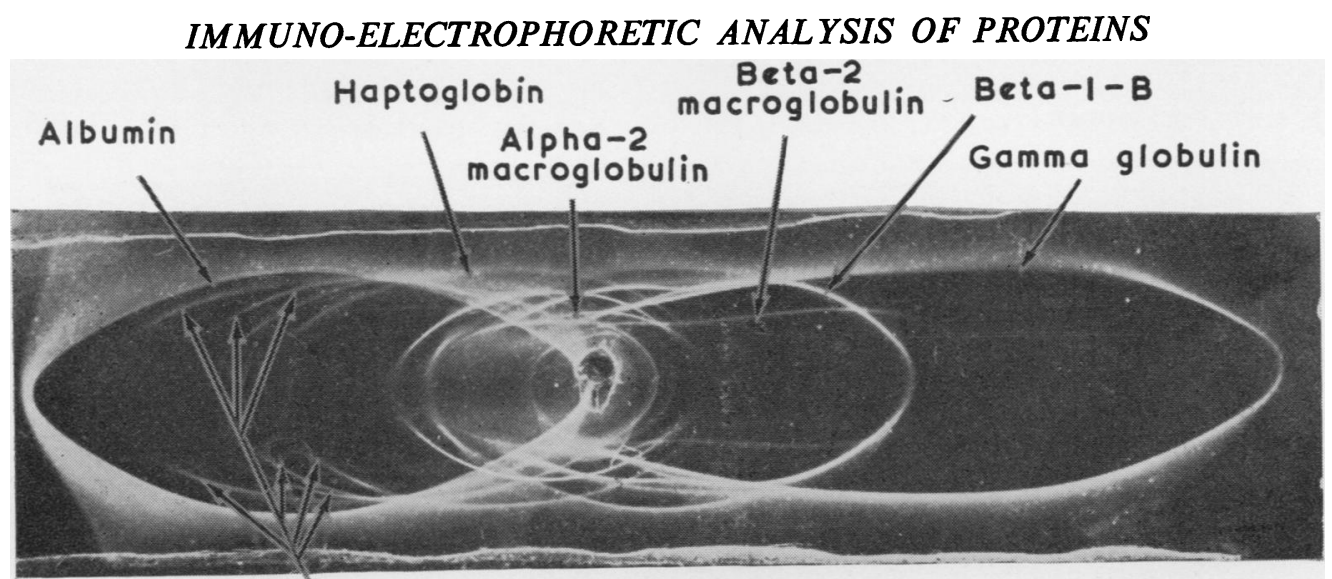

Alpha-I-globulin

Fig. 2.-Increase of alpha-1 globulin, dense band of haptoglobin, alpha-2 macroglobulin, beta-2 macroglobulin, and beta-1-B globulin.

Antiserum: Rabbit-antihuman-rheumatoid serum.

Antigen: Serum from patient with rheumatoid arthritis (functional capacity Grade II, E.S.R. 110 to $127 \mathrm{~mm}$./ $/ \mathrm{hr}$, haemagglutination titre $1: 1,024)$.

Paper Electrophoresis: Albumin 39.0 per cent., Alpha-1 globulin 5.4 per cent., Alpha-2 globulin $12 \cdot 3$ per cent., Beta-1 globulin $11 \cdot 2$ per cent., Gamma globulin $32 \cdot 1$ per cent.

\section{Albumin}
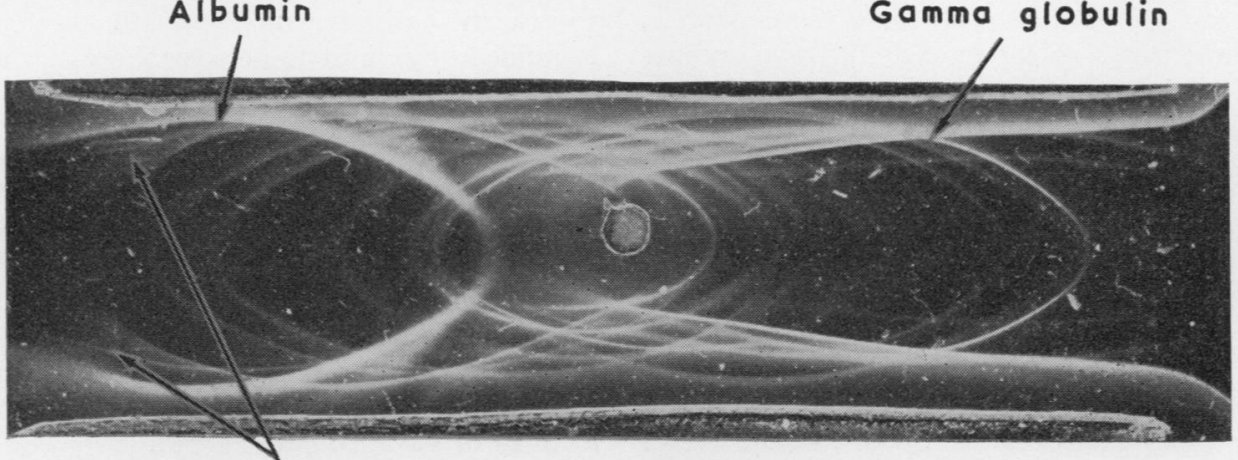

Acid seromucoid

Fig. 3.-Well-marked band of acid seromucoid.

Antiserum: Rabbit-antihuman-rheumatoid serum.

Antigen: Synovial fluid from the same patient as in Figure 2.

Haptoglobin

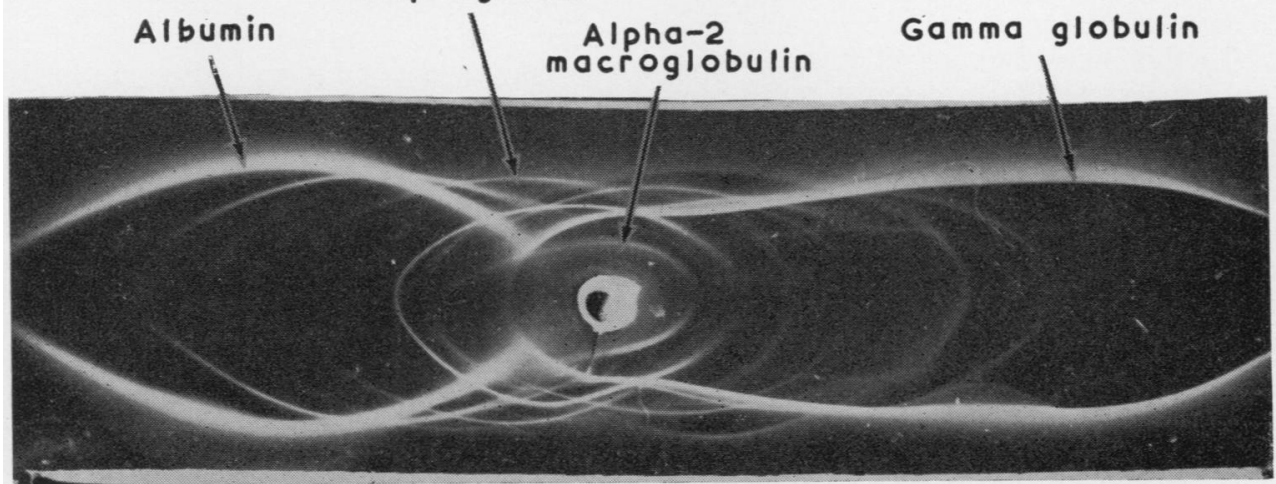

Fig. 4.-Dense band of haptoglobin, alpha-2 macroglobulin, and beta-2 macroglobulin.

Antiserum: Rabbit-antihuman-rheumatoid serum.

Antigen: Serum from patient with rheumatoid arthritis (functional capacity Grade III, E.S.R. 60 to $90 \mathrm{~mm}$./hr, haemagglutination titre $1: 64$ ).

Paper Electrophoresis: Albumin 48.0 per cent., Alpha-1 globulin 4.7 per cent., Alpha-2 globulin 9.0 per cent., Beta globulin $11 \cdot 8$ per cent., Gamma globulin $26 \cdot 2$ per cent. 


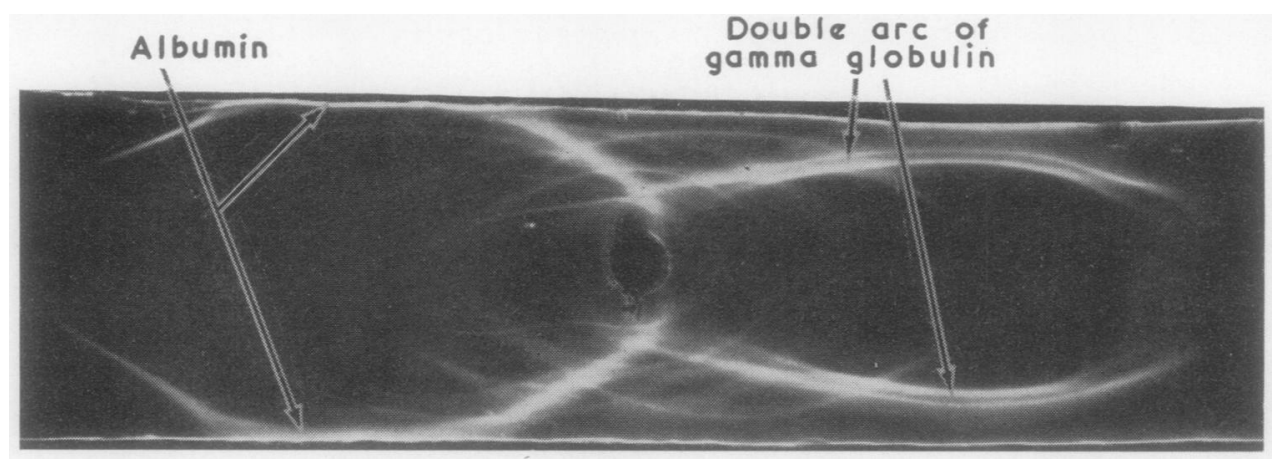

Fig. 5.-Double arc of gamma globulin.

Antiserum: Rabbit-antihuman-rheumatoid serum.

Antigen: Serum from patient with rheumatoid arthritis (functional capacity Grade III, E.S.R. 110 to $125 \mathrm{~mm} . / \mathrm{hr}$. haemagglutination titre $1: 1,024)$.

Paper Electrophoresis: Albumin $40 \cdot 5$ per cent., Alpha-1 globulin $4 \cdot 3$ per cent., Alpha-2 globulin $9 \cdot 9$ per cent., Beta-globulin $11 \cdot 3$ per cent., Gamma globulin $34 \cdot 0$ per cent.

those from two patients with renal disease, in whose sera alpha-2 lipoprotein was also demonstrable. This component was subdivided into two moities differing slightly in their electrophoretic mobility (i.e. "slow" and "fast").

Beta-1 Globulin.-A dense precipitate of beta-1-B globulin was produced with seven of the sera from patients with rheumatoid arthritis by the rabbit antisera to serum from patients with renal disease (Fig. 2). Increased amounts of beta-1 lipoprotein were present in the serum of these two patients.

Beta-2 Globulin.-Three components of this fraction were identified as beta-2 A, beta- $2 \mathrm{~B}$, and beta- 2 $M$. There was evidence of a fourth component in this fraction of the sera obtained from four of the healthy individuals. This precipitate appeared only when these were tested with rabbit antiserum prepared against serum from the patients with renal disease. The component has not yet been identified.

The precipitates attributed to the A and B components varied too much to permit adequate description, and only the $\mathbf{M}$ component will be considered. This was increased in 35 ( 81 per cent.) of the sera obtained from patients with rheumatoid arthritis, in fifteen ( 68 per cent.) of those from patients with ankylosing spondylitis, and in three (15 per cent.) of those from healthy individuals (Figs 2 and 4).

Gamma Globulin.-This fraction usually has a single immuno-electrophoretic component. However, eight sera from the patients with rheumatoid arthritis and two from patients with ankylosing spondylitis produced an additional precipitin line, parallel to the first, suggesting the presence of two distinct antigenic components in the gamma globulin fraction (Fig. 5). This possibility is discussed later.
Synovial Fluid.-Proteins in the synovial fluids $\stackrel{\circ}{?}$ from eight patients with rheumatoid arthritis were $\overrightarrow{\mathcal{S}}$ examined by immuno-electrophoresis, and the $\mathbb{D}$ concentrations of several components were com- $\overrightarrow{\mathbb{D}}$ pared with those of the same components of serum 3 proteins. In six of the eight synovial fluids the $\stackrel{\Phi}{-}$ concentration of alpha- 2 and beta-1 lipoproteg $\overrightarrow{0}$ and of beta-2 macroglobulin was significant lower than in the corresponding sera. A den band of precipitate corresponding with acid mucto protein of serum was observed in the patterns produced by the synovial fluids obtained from three rheumatoid patients with active inflammatory features of recent onset (Fig. 3).

Urine.-In immuno-electrophoresis, urine from $\overline{\bar{O}}$ the two patients with rheumatoid arthritis and renal disease produced seven or eight distinct precipitin lines (Fig. 6, opposite). The samples of urine contained 7 to $18 \mathrm{~g}$. protein per litre, and the com- $\frac{\stackrel{0}{0}}{2}$ ponents producing the most dense precipitates were identified as albumin, alpha-1 proteins, alpha-2 3 . proteins, siderophilin, and gamma globulin.

\section{Discussion}

It is possible to measure the concentration of the $D$ major electrophoretic fractions of serum as percentages of the total protein in the sample, and to $\bar{N}$ calculate absolute concentration from these data. $\%$ Similar quantitation of immuno-electrophoretic $\stackrel{N}{\circ}$ components is not yet possible and although some $\underset{\omega}{\mathrm{N}}$ information is provided by the intensity and position of the precipitates, these characteristics are partlyo determined by the antigenic potency of individual $\frac{\varnothing}{\varnothing}$ proteins. A number of proteins may be present in $\stackrel{\mathcal{D}}{+}$ only small amounts (e.g. alpha- 2 and beta- 2 macro- $\square$ globulins) and yet induce relatively large amounts $\frac{\vec{D}}{\vec{D}}$ 


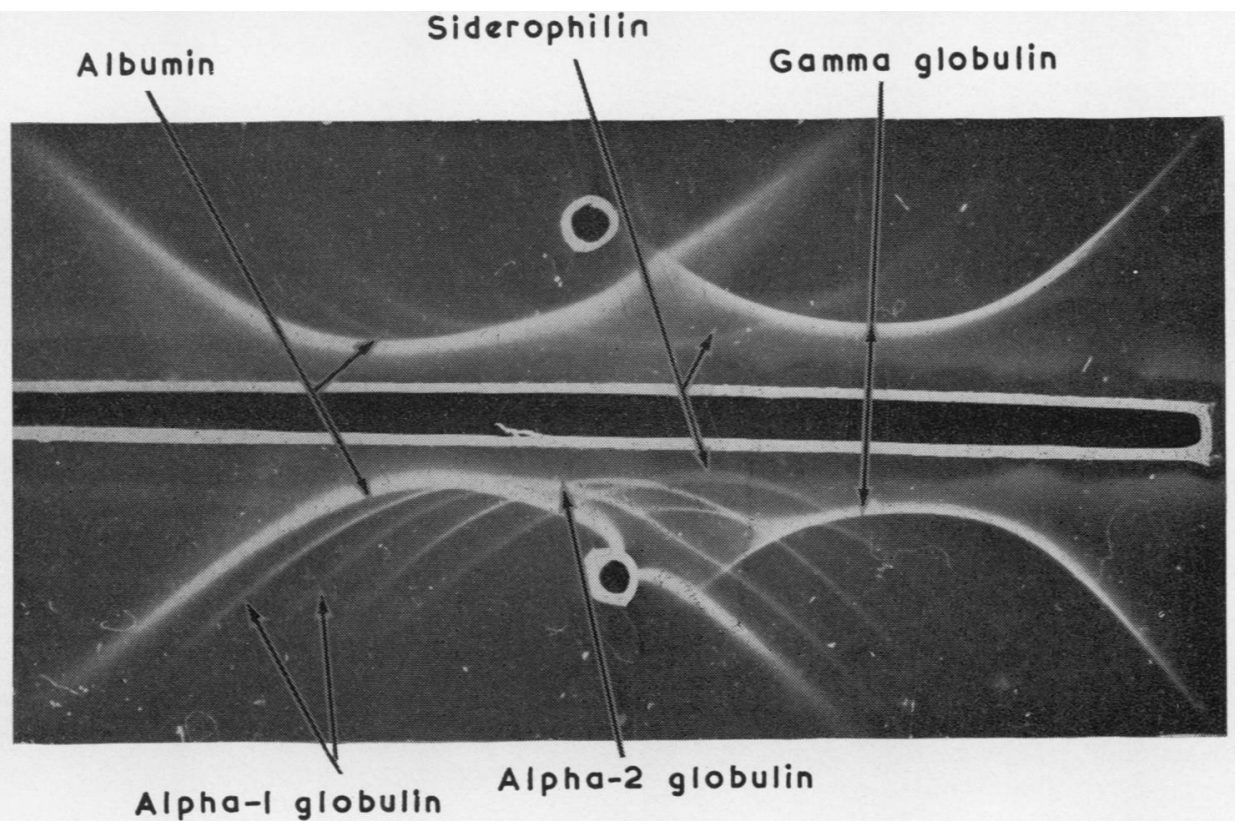

Fig. 6.-Upper: chronic nephrotic syndrome (proteinuria $18 \mathrm{~g} . /$ litre). Lower: amyloidosis (proteinuria $15 \mathrm{~g}$./litre). Antiserum: Rabbit-antihuman-nephrotic serum.

Antigen: Urine from two patients with rheumatoid arthritis and renal disease.

of specific antibody in a polyvalent antiserum, with the consequent formation of dense precipitates on immuno-electrophoresis.

In the present investigations, quantitation of individual components relative to the same components in standard sera was attempted by methods involving dilution or selective absorption. The quantitative changes thus demonstrated in sera from patients with rheumatic disease were in general not paralleled by comparable changes in the major electrophoretic fractions, and it seems likely that paper electrophoresis and immuno-electrophoresis are complementary rather than interchangeable methods of analysis (Table).

All the abnormalities of serum proteins found on immuno-electrophoresis occurred in both rheumatoid arthritis and ankylosing spondylitis and with approximately the same incidence. The possibility remains that extended investigation may reveal differences between the two diseases in terms of serum proteins and their sub-fractions. However, the changes so far demonstrated appear to be nonspecific manifestations of inflammation occurring in both diseases.

The most frequently observed abnormality was the presence of an increased amount of beta- 2 macroglobulin; this was demonstrated in 81 per cent. of the sera from patients with rheumatoid arthritis and in 68 per cent. of those from patients with ankylosing spondylitis. This difference in incidence between the groups is not significant:

$$
\chi^{2}=0.8 ; 0.5>P>0.3 \text {. }
$$

The abnormality appears to be associated with active inflammation and has been previously observed in active rheumatoid arthritis by Cleve and Hartmann (1957), Cleve (1958), Fenrych and others (1959), Mackiewicz and Fenrych (1959), and Francq and others (1959). Because increased amounts of this macroglobulin were found in sera with a normal sheep cell agglutination titre and in those with a high titre, it is evident that the amount of beta- 2 macroglobulin was unrelated to the presence or absence of rheumatoid factor. According to Burtin (1960), the beta- 2 macroglobulin includes a number of proteins differing in physiological properties but having identical basic antigenic structures. The lack of correlation between the sheep cell titre and the concentration of the macroglobulin is therefore not evidence against the rheumatoid factor being a member of this family of proteins.

Many of the sera from rheumatic patients gave rise to precipitates of increased density in the bands identified as alpha-1 and alpha-2 glycoprotein, acid seromucoid, haptoglobin, and alpha-2 macroglobulin. Such changes were demonstrable with 
sera from rheumatoid patients in all functional grades, but were less frequent with sera from spondylitic patients; their significance remains unknown.

The double precipitate of gamma globulin which occurred with some sera has been reported previously. While the double arc is unusual (Grabar and Williams, 1955) and may sometimes occur as an artefact due to temperature changes during diffusion, true duplication is a reproducible phenomenon when particular antisera are used. A double band produced by sera from infants and children was reported by Hitzig (1957) and by Giedion and Scheidegger (1957). In adults the anomaly was found by Schultze and Schwick (1957) in chronic hepatitis, chronic nephrosis, and reticulosis. A double gamma globulin precipitate was also produced by sera from patients with reticulosis (Creyssel, Fine, and Morel, 1959) and by sera from some patients with rheumatoid arthritis (Fenrych and others, 1959). Recently also, Grabar and Burtin (1960) emphasized the immunological heterogeneity of gamma globulin. The significance of such heterogeneity remains unknown and requires further investigation.

\section{Summary}

Immuno-electrophoretic analysis was performed on sera from 43 patients with rheumatoid arthritis and 22 patients with ankylosing spondylitis, on synovial fluid from eight patients with rheumatoid arthritis, and on urine from two patients with rheumatoid arthritis complicated by renal disease.

In many sera from patients with rheumatoid arthritis and ankylosing spondylitis there were increased amounts of alpha-1 and alpha-2 glycoproteins.

The most constant finding in both groups was an increased amount of beta- 2 macroglobulin. In sera from some patients with rheumatoid arthritis and ankylosing spondylitis, a double arc of gamma globulin was found. The significance of this finding is discussed.

Immuno-electrophoretic patterns of synovial fluid and urine were compared with the patterns of sera from the same patients.

We are much indebted to Dr. J. L. Potter and Dr. J. J. R. Duthie for their helpful advice. We wish to thank Dr. P. Burtin from the Institut Pasteur, Paris, for helping to interpret some of the immuno-electrophoretic patterns.

\section{REFERENCES}

Benacerraf, B., Potter, J. L., McCluskey, R. T., and Miller, F. (1960). J. exp. Med., 111, 195.
Burtin, P. (1960). In "Ciba Foundation Symposium $\frac{}{3}$ on Cellular Aspects of Immunity", p. 213. 므 Churchill, London.

(1961). Personal communication.

Chodera, A. and Mackiewicz, S. (1958). Przegl. lek., 14, No. 4, p. 113.

Cleve, H. (1958). $Z$. Rheumaforsch., 17, 350.

- and Hartmann, F. (1957). Klin. Wschr., 35, 334. $\frac{\bar{\rho}}{\frac{\rho}{\sigma}}$

Creyssel, R., Fine, J. M., and Morel, P. (1959). Rev. $\mathbb{\complement}$ Hémat., 14, 238.

Fenrych, W., Jazienicki, B., Mackiewicz, S., Mackiewicz, ळ U., and Twardowski, K. (1959). Pol. Tyg. lek., $\vec{\circ}$ 14, 1937.

Francq, J., Eyquem, A., Podliachouk, L., and Jacqueline, $\vec{\omega}$ F. (1959). Ann. Inst. Pasteur, 96, 413.

Giedion, A., and Scheidegger, J. J. (1957). Helv. paediat. Acta, 12, 241.

Grabar, P. (1960). Triangel, 4, 185. and Burtin, P. (1960). "L'analyse immuno- ") electrophorétique". Masson, Paris. and Williams, C. A. (1953). Biochim. biophys. Acta, 10, 193.

(1955). Ibid., 17, 67.

Hitzig, W. H. (1957). Helv. paediat. Acta, 12, 596.

Mackiewicz, S., and Fenrych, W. (1959). Postepy Hig. Med. dósw., 13, 809.

McCluskey, R. T., Benacerraf, B., Potter, J. L., and Miller, F. (1960). J. exp. Med., 111, 181.

Ouchterlony, O. (1953). Acta path. scand., 32, 231. $8 \overrightarrow{0}$

Scheidegger, J. J. (1955). Int. Arch. Allergy, 7, 103 은 오

Schmid, K., and MacNair, M. B. (1956). J. clin. Inve适; $35,814$.

Schultze, H., and Schwick, J. (1957). Behringwerke Mitteilungen, heft 33 .

Analyse immuno-électrophorétique des protéines sériques $\stackrel{\unrhd}{\mathscr{Q}}$ RÉSUMÉ

On procéda à l'analyse immuno-électrophorétique 3 des sérums de 43 malades atteints d'arthrite rhumatismale et de 22 malades atteints de spondylarthrite ankylosante,, des liquides synoviaux de 8 malades atteints d'arthrite rhumatismale et de l'urine de 2 malades atteints d'arthrite rhumatismale compliquée d'une maladie rénale.

Dans le sérum de beaucoup de cas d'arthrite rhumatismale et de spondylarthrite ankylosante on trouva des $\bar{z}$. taux augmentés de glucoprotéine alfa- 1 et alfa- 2 .

Le résultat le plus constant dans les deux groupes fut 3 une augmentation de la beta-2 macroglobuline. Dans les sérums des cas d'arthrite rhumatismale et de spondyl-음 arthrite ankylosante on trouva un double arc de globuline gamma. On discute l'importance de ce résultat.

Les tableaux immuno-électrophorétiques du liquide synovial et de l'urine furent comparés à ceux offert par les sérums des mêmes malades.

\section{Análisis imuno-electroforético de las proteinas séricas}

\section{SUMARIO}

Se llevaron a cabo análisis imuno-electroforéticoso en sueros procedentes de 43 enfermos con artritis reuma-c toide y 22 con espondilartritis anquilosante, en líquido@ sinovial de ocho enfermos con artritis reumatoide y en. orina de dos enfermos con artritis reumatoide complicada 0 con enfermedad renal. 
En el suero de muchos de los enfermos con artritis reumatoide y espondilartritis anquilosante se encontró un aumento de la cantidad de alfa-1 y alfa-2 glucoproteinas.

El hallazgo mas constante en ambos grupos fué el aumento de beta-2 macroglobulina. En sueros de enfermos con artritis reumatoide y espondilartritis anquilosante se encontró un doble arco de gama globulina. Se discute el significado de dicho hallazgo.

Los cuadros imuno-electroforéticos del líquido sinovial y de la orina fueron comparados con los hallados en el suero de los mismos enfermos. 